\title{
Correction to: Long non-coding RNA H19 promotes colorectal cancer metastasis via binding to hnRNPA2B1
}

Yuhui Zhang ${ }^{1 \dagger}$, Weibin Huang ${ }^{1 \dagger}$, Yujie Yuan ${ }^{1 \dagger}$, Jin $\mathrm{Li}^{2}$, Jing $\mathrm{Wu}^{2}$, Jie Yu${ }^{1}$, Yulong $\mathrm{He}^{1,2^{*}}$, Zhewei Wei ${ }^{1^{*}}$ and Changhua Zhang ${ }^{2^{*}}$

\section{Correction to: J Exp Clin Cancer Res 39, 141 (2020) https://doi.org/10.1186/s13046-020-01619-6}

Following publication of the original article [1], the authors identified minor errors in image-typesetting in Fig. 2; specifically the migration transwell assay of shH19-2 DLD1 cells group displayed in Fig. 2d.

The corrected figure is given below. The correction does not have any effect on the results or conclusions of the paper. The original article has been corrected.

The original article can be found online at https://doi.org/10.1186/s13046020-01619-6.

* Correspondence: heyulong@mail.sysu.edu.cn; denisewei@126.com; zhchangh@mail.sysu.edu.cn

†Yuhui Zhang, Weibin Huang and Yujie Yuan contributed equally to this work.

'Department of Gastrointestinal Surgery, the First Affiliated Hospital of Sun Yat-sen University, 58 Zhongshan 2nd Road, Guangzhou 510080,

Guangdong, China

${ }^{2}$ Center for Digestive Disease, the Seventh Affiliated Hospital of Sun Yat-sen

University, 628 Zhenyuan Road, Shenzhen 518000, Guangdong, China

C C The Author(s). 2021 Open Access This article is licensed under a Creative Commons Attribution 4.0 International License, which permits use, sharing, adaptation, distribution and reproduction in any medium or format, as long as you give appropriate credit to the original author(s) and the source, provide a link to the Creative Commons licence, and indicate if changes were made. The images or other third party material in this article are included in the article's Creative Commons licence, unless indicated otherwise in a credit line to the material. If material is not included in the article's Creative Commons licence and your intended use is not permitted by statutory regulation or exceeds the permitted use, you will need to obtain permission directly from the copyright holder. To view a copy of this licence, visit http://creativecommons.org/licenses/by/4.0/ The Creative Commons Public Domain Dedication waiver (http://creativecommons.org/publicdomain/zero/1.0/) applies to the data made available in this article, unless otherwise stated in a credit line to the data. 


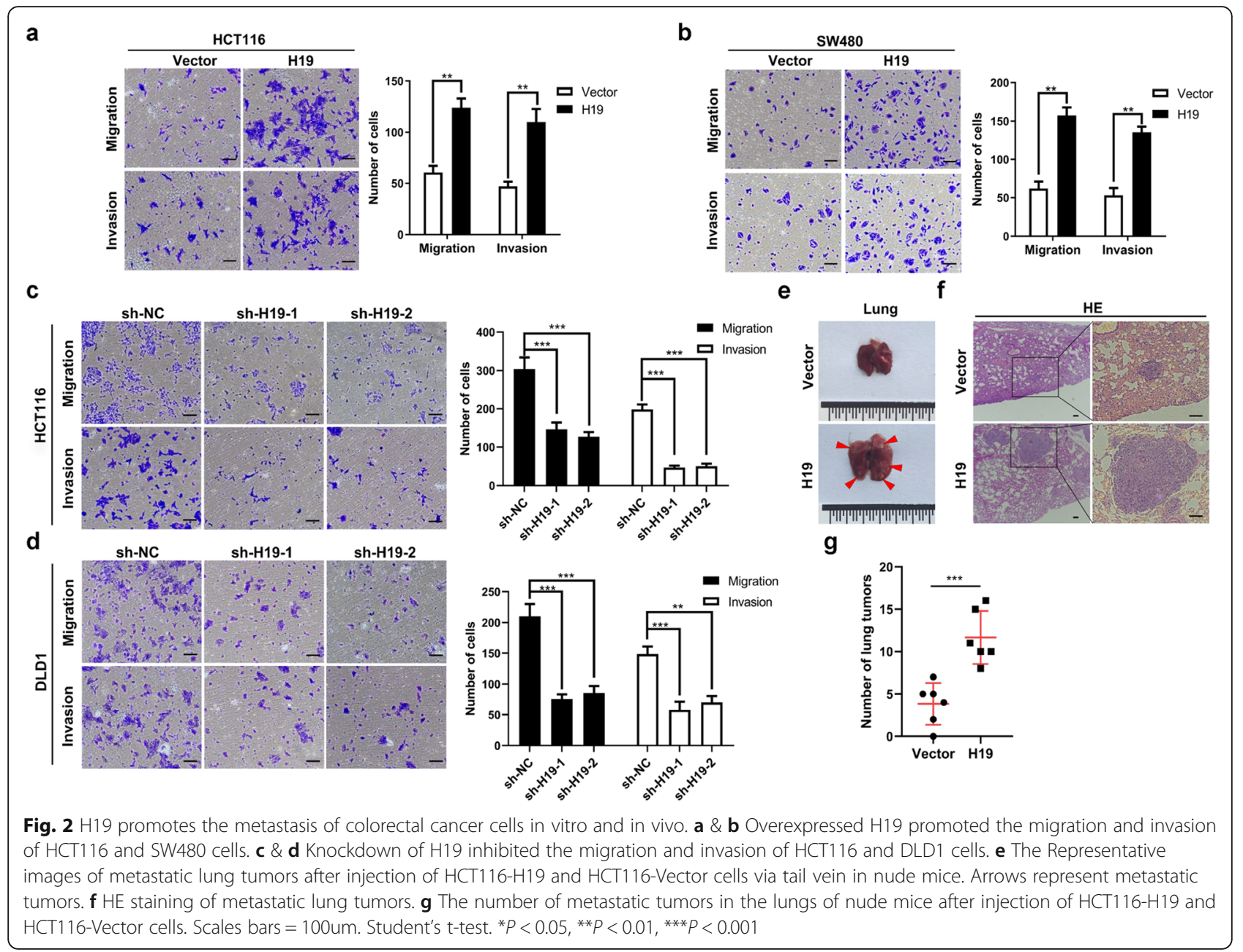

Published online: 23 March 2021

\section{Reference}

1. Zhang $Y$, Huang $W$, Yuan $Y$, et al. Long non-coding RNA H19 promotes

colorectal cancer metastasis via binding to hnRNPA2B1. J Exp Clin Cancer Res. 2020;39:141. https://doi.org/10.1186/s13046-020-01619-6. 